\title{
MENCARI NILAI HORMAT DAN RUKUN PADA TAYANGAN OPERA VAN JAVA DI TRANS 7
}

\author{
Retno Manuhoro Setyowati, Yuliyanto Budi Setiawan, Hastika Yanti Nora \\ E-mail: retno@ftik.usm.ac.id; youlee_wa2n@yahoo.co.id; hastika@ftik.usm.ac.id \\ (Staf Pengajar Program Studi Ilmu Komunikasi Universitas Semarang)
}

\begin{abstract}
As a form of puppet people development standard, Opera Van Java (OVJ) which aired on Trans 7 can be regarded as puppets of the grip of revolution on a large scale given the characteristics of the OVJ them is to use the Indonesian language and do not use master narratives. OVJ phenomenon is developing a play slapstick tradition of Mataram who first appears. If all this a play performed on the dimensions of verbal (words / sentences), in this OVJ also other aspects of the thematic core of which is actors, morality story, characterization of his characters, costumes, music, and even setting the stage. Opera Van Java turned into popular culture in the form of puppet people are loaded with innovation and reintepretation.
\end{abstract}

Kata Kunci: Opera Van Java, Puppet People Development Standard, Popular Culture, Slapstick Tradition.

\section{Pendahuluan}

Budaya Jawa merupakan suatu budaya yang menarik untuk diamati, sekalipun tidak sedikit peneliti yang berminat menggali pola-pola kehidupan yang mendasari masyarakat Jawa dan bahkan peneliti-peneliti luar negeri pun banyak menaruh perhatian dengan budaya Jawa seperti misalnya Clifford dan Hildred Geertz, Niels Mulder, dan lain sebagainya. Frans Magnis Susesno misalnya, seorang warganegara Jerman yang mendalami budaya Jawa; didalam bukunya yang berjudul etika Jawa mengatakan bahwa kebudayaan Jawa ciri khasnya terletak pada kemampuannya yang luar biasa untuk membiarkan diri dibanjiri oleh gelombang-gelombang kebudayaan yang datang dari luar. Namun pada banjir itu ia tetap dapat mempertahankan keasliannya. Kebudayaan Jawa dinilai mudah lebur dalam masukan-masukan kultural dari luar. Hinduisme dan Budhisme dirangkul, tetapi akhirnya "di Jawakan".
Agama Islam masuk ke pulau Jawa, tetapi kebudayaan Jawa hanya semakin menemukan identitasnya.

Menurut Hildred Geertz, ada dua kaidah dasar dalam kehidupan Jawa atau yang biasa disebut sebagai Kejawen. Yang pertama adalah sekelompok nilai yang berkenaan dengan pandangan Kejawen tentang tata krama "penghormatan" , dan yang kedua adalah nilai-nilai yang berkenaan dengan pengutamaan orang Jawa terhadap terpeliharanya "penampilan sosial yang harmonis" atau yang disebut dengan istilah rukun. Sekalipun kedua nilai ini tidaklah dengan sendirinya menjamin daya upayanya secara aktif untuk meraihnya dan tidak pula menjamin tercapai nilai itu, namun biasanya orang Jawa benar-benar berhasil dalam usaha bertindak-tanduk selaras dengan nilai-nilai tersebut, baik dalam keluarga maupun dalam lingkungan masyarakat mereka. Nilainilai tersebut hidup dalam keseharian masyarakat Jawa dan menjelma dalam 
berbagai bentuk atau hasil kebudayaan. Diantara sekian banyak hasil kebudayaan, yang nampak jelas adalah melalui hasil kebudayaan yang berwujud (materiil) misalnya seperti seni tari, wayang, dan sebagainya.

Secara material seni pertunjukan berwujud sesuatu (wayang orang, ketoprak, musik, tari, dan lain-lain) memberi sentuhan rasa indah, senang dan puas. Singkatnya, seni pertunjukan memiliki dimensi sebagai pelipur rasa atau hiburan. Dalam konteks ini tidak dapat diingkari bahwa hal-hal yang bersangkutan dengan cita rasa menjadi unsur-unsur yang sangat diperhatikan. Tetapi karya seni pertunjukan yang utuh bukan hanya memperhatikan dimensi yang material (sosoknya) saja melainkan juga dimensi yang substansial dalam keseimbangan yang tepat. Oleh karena itu, karya seni pertunjukkan selain memberi hiburan, kepuasan dan cita rasa juga menyampaikan pesan sang seniman berupa nilai-nilai, penghayatan kehidupan, hati nurani, perhatian, cinta, hakekat dan sebagainya. Sementara menyaksikan seni pertunjukkan selain untuk menghibur diri juga untuk memperoleh reverensi pandangan hidup, nilai-nilai yang dipahaminya dengan apa yang disampaikan oleh sang seniman dalam seni pertunjukkannya. Maka terjadilah suatu interaksi budaya keberadaan mereka dalam perjalanan dan proses kelangsungan kehidupan.

Terkait dengan dua nilai dasar dalam kehidupan Jawa, di dalam aneka bentuk kesenian, spirit utama itu harus tetap ada dan hidup dalam setiap gerakgeriknya. Karena sifatnya yang lentur dan mudah lebur, maka berbagai wujud kebudayaan tersebut mudah diadopsi dan menyesuaikan diri dengan perkembangan jaman. Dari yang pada awalnya berupa seni tontonan asli, lalu dipindah tempatkan dan dikemas menjadi tontonan yang menghibur di televisi. Perkembangan media massa yang pesat inilah yang membuat aneka bentuk kebudayaan menyesuaikan diri dengan segala kepentingan ekonomi media. Semuanya seolah berubah menjadi budaya popular dan membawa konsekwensi adanya perubahan nilainilai yang melingkupinya.

Sebagai salah satu wujud transformasi bentuk kebudayaan asli menjadi kebudayaan popular adalah Opera van Java (OVJ). Kehadirannya menjadi pelengkap atas berbagai olahan kesenian rakyat yang menyesuaikan diri dengan media massa (televisi). Sebagai bentuk dari pengembangan wayang orang pakem, OVJ bisa dikatakan sebagai revolusi wayang orang pakem secara besar-besaran, mengingat karakteristik pada OVJ diantaranya adalah menggunakan bahasa Indonesia dan tidak menggunakan cerita-cerita pakem. Fenomena OVJ ini mengembangkan tradisi plesetan dagelan Mataram yang lebih dulu muncul. Kalau selama ini plesetan dilakukan pada dimensi verbal (katakata / kalimat), pada OVJ ini juga memplesetkan segi-segi lainnya yaitu diantaranya adalah inti tematik lakonnya, moralitas ceritanya, perwatakan tokoh-tokohnya, kostumnya, musiknya, bahkan setting panggungnya. Opera Van Java berubah menjadi wayang orang yang sarat dengan inovasi dan reintepretasi.

Adapun rumusan masalah yang ingin dibedah dalam penelitian ini adalah: Sekalipun Opera Van Java telah mengalami banyak perubahan dalam penampilan dan penyajiannya, apakah nilai-nilai budaya Jawa yang menekankan pentingnya prinsip hormat dan rukun masih terkandung di dalamnya? Bagaimanakah nilai-nilai budaya Jawa semacam itu ditampilkan dalam Opera Van Java? 
Selanjutnya, dalam penelitian ini, dilakukan pembatasan masalah, dari beberapa permasalahan yang diidentifikasi. Hal ini dilakukan karena terbatasnya kemampuan peneliti (baik kemampuan substantif, metodologis, maupun teknis) dan terbatasnya waktu, sehingga berbagai permasalahan penelitian yang telah teridentifikasi tidak mungkin dapat ditangani oleh peneliti sekaligus. Permasalahan dibatasi pada mencari nilai hormat dan rukun saja sebagai dua nilai mendasar masyarakat Jawa dalam tayangan OVJ.

Sementara itu, peranan komunikasi dapat dianggap sebagai pembawa kebudayaan yang penting. Media komunikasi adalah alat kultural yang mendorong atau mempengaruhi sikap, memberi motivasi, mengembangkan pola tingkah laku, dan menyebabkan integrasi sosial. Komunikasi berperan utama dalam menerapkan kebijakan kebudayaan dan membantu mendemokrasikan kebudayaan. Bagi jutaan orang, komunikasi merupakan sarana utama dalam mengenal kebudayaan dan semua bentuk yang kreatif (Mac Bride, 2010: 23). Menurut Mac Bride, komunikasi juga berperan dalam mengelola ilmu pengetahuan, organisasi ingatan kolektif masyarakat dan khususnya pengumpulan, pemrosesan, dan penggunaan informasi ilmu pengetahuan. Akhirnya, ia mampu membentuk kembali kebudayaan masyarakat. Eksistensi media massa televisi sebagai hasil kemajuan ilmu pengetahuan teras mempunyai arti yang besar di tengah-tengah masyarakat yang saat ini sedang melakukan modernisasi dan pembangunan dalam kaitannya dengan upaya pelestarian seni tradisional.

Berbicara mengenai komunikasi, kita tidak akan lepas dari unsur kebudayaan suatu masyarakat, karena suatu komunikasi massa yang berlangsung dalam suatu negara itu ditentukan oleh lingkungan masyarakat dimana pun ia berada. Dalam banyak hal, hubungan antara budaya dan komunikasi bertindak timbal balik. Keduanya saling mempengaruhi. Apa yang kita bicarakan, bagaimana kita membicarakannya, apa yang kita lihat atau bakan diabaikan. Pada gilirannya, apa yang kita bicarakan, bagaimana kita membicarakannya dan apa yang kita lihat membentuk, menentukan dan menghidupkan budaya kita. Budaya tak akan hidup tanpa komunikasi, dan komunikasi pun takkan hidup tanpa budaya. Masing-masing tak dapat berubah tanpa menyebabkan perubahan yang lain (Richard E. Porter, 1998: 34).

Seorang ahli antropologi, Ralph Linton memberikan definisi kebudayaan sebagai seluruh cara kehidupan dari masyarakat yang mana pun dan tidak hanya mengenai sebagian dari cara hidup itu yaitu bagian yang oleh masyarakat dianggap lebih tinggi atau lebih diinginkan. Secara umum, kebudayaan menunjuk pada berbagai aspek kehidupan yang meliputi caracara berperilaku, kepercayaankepercayaan dan sikap-sikap juga hasil dari kegiatan manusia yang khas untuk suatu masyarakat atau kelompok penduduk tertentu. Maka tidak heran bila suatu tindakan komunikasi seringkali mengungkap kebudayaan yang menghiasi kehidupan suatu masyarakat tertentu. Dan saat ini melalui media massa pula suatu kebudayaan dilestarikan dan di transmisikan. Hal ini sesuai dengan teori global village yang dikemukakan oleh Marshal Mc. Luhan. Hambatan geografis kini telah sirna, perkembangan teknologi informasi telah menjadikan kondisi penghuni bumi sebagai wadah raksasa yang disebut dengan "Desa Dunia". Sehingga jarak bukan menjadi 
hambatan lagi bagi umat manusia untuk saling berkirim informasi, dan dalam hal ini televisi juga menjadi bagian dari pendukung fasilitas desa dunia.

Sebagai pranata sosial, televisi yang masuk sebagai bagian dari media massa berfungsi melakukan pengendalian sosial (social control) di tengah kehidupan masyarakat. Efektif atau tidaknya social control yang dilakukan oleh media massa, akan tergantung pada integritas media massa itu sendiri serta tingkat kepercayaan masyarakat terhadap media massa yang bersangkutan (Sasangka, 2008: 32). Media massa sendiri menjadi objek pengendalian sosial yang dilakukan oleh masyarakat. Untuk keperluan itu bahkan diadakan sejumlah pranata lain seperti badan sensor, dewan kehormatan pers dan sebagainya. Jadi pengawasan sosial yang berlangsung sifatnya adalah timbal balik antara media massa dengan masyarakat itu sendiri (Haryatmoko, 2007: 45).

Sementara itu, Opera Van Java (OVJ) diisi oleh nama-nama artis seperti: Parto, Sule, Andre Taulani, Aziz 'Gagap' dan Nunung. Wajahwajah mereka hampir tiap hari muncul di Trans 7, sebagai salah satu stasiun televisi nasional. Dalam OVJ Parto yang bertindak sebagai sang dalang dan menjadi penggerak pemainnya yakni Andre taulani, Sule, Azis Gagap, dan Nunung. Tak hanya itu, dalang pun ditemani oleh sinden yang selalu bernyanyi setiap sang pemain memulai adegan dan di iringi oleh musik gemelan. Keunikan muncul ketika sebenarnya program yang di sadur dari wayang wong, yaitu dalangnya beserta wayang atau pemainnya dapat bertindak sesuka hati sesuai dengan keinginan dalang dan lepas dari keajegan formulasi wayang wong. Format atau tampilan yang berbeda terhadap sebuah seni tradisi sebenarnya bukan kali ini saja terjadi. Konsekuensi ini di ambil untuk memenuhi keinginan pasar yang mampunyai minat tinggi terhadap seni rakyat, tetapi tidak memiliki antusias tinggi untuk mengikuti jalannya acara seni tradisi. Sebelum OVJ kita pernah mendangar Ludruk Glamor, Ketoprak Humor, ataupun Srimulat. Hanya saja, OVJ menjadi sebuah penyajian yang istimewa karena ditempatkan pada kondisi lesunya acara hiburan berbalut budaya atau seni rakyat. Melihat fenomena yang terjadi pada OVJ maka secara langsung akan terhubung dengan kepentingan budaya kapitalis saat ini. OVJ sebenarnya adalah sebuah produk dari budaya popular yang merajalela di Indonesia, terutama dengan budaya konsumerisme dan kapitalisme. Para pemilik modal dan juga korbannya, konsumen, menjadi sebuah titik inti diciptakan sebuah bentuk kebudayaan. OVJ salah satunya masuk dalam kategori populer yang mau tidak mau pun berorientasi pada massa beserta alibi postifnya untuk melestarikan budaya tradisional.

Menurut Umar Kayam, dalam kebudayaan istilah pop dibedakan dengan populer. Secara etimologis, istilah populer dikaitkan dengan massa, yaitu masyarakat banyak. Istilah pop art berhubungan dengan masyarakat kecil atau masyarakat minoritas (Graeme, 2008 : 21) Lain halnya dengan di Indonesia, perkembangan seni pop pada umumnya disamakan dengan seni populer. Selanjutnya makna populer yang berkaitan dengan OVJ di konsistensikan tanpa mendikotomi antara pop art yang bercorak minoritas serta eksperimental dan popular art yang bercorak mayoritas. Secara kasat mata, kepopuleran OVJ terletak pada bentuk eksperimental yang selanjutnya disebut kiscth, dan penyajiannya dan juga berorintasi pada massa. Sebagai 
bentuk saduran dari wayang wong, OVJ mencoba mempertahankan sesuatu yang 'ajeg' dan juga memberi sentuhan baru yang inovatif. Kesesuaian yang ajeg merupakan bagian dari budaya populer karena sudut pandang sudah dikenalnya budaya ini. Dalam kebudayaan Indonesia, keberadaan pop art atau budaya tinggi dan populer atau budaya rendah telah dikenal dengan sebutan seni tradisi dan seni rakyat. Seni tradisi dan seni rakyat memang berbeda. Seni tradisi hidup di kota. Kesenian ini merupakan kelanjutan dari kesenian yang hidup dan berkembang di sekitar keratin atau tempat kekuasaan. Sedangkan seni rakyat tumbuh di desa, di tengah masyarakat kecil yang dalam segala hal Nampak jelas perbedaan kepemilikan (Lindsay, 1999: 22). Selanjutnya, kesenian tradisional dapat disebut juga dengan kesenian modern, yaitu sebagai bentuk seni yang penggrapannya didasarkan atas cita rasa di kalangan masyarakat pendukung. Cita rasa ini biasanya berupa penemuan dan pembaruan. Pembaruan dan penemuan adalah ciri utama pop art sehingga dapat disamakan dengan seni tradisi. OVJ adalah perpaduan dari kesenian yang berbeda alam. Begitu halnya dengan kesenian Indonesia yang dapat hidup di dua lingkungan kebudayaan. OVJ sebagai bentuk sadur dari wayang wong merupakan bentuk kepemilikan masyarakat tertentu terhadap kesenian ini. Dalam konteks ke-Indonesiaan, kepemilikan dan petumbuhannya pada masyarakat tertentu disebut juga kebudayaan daerah. Kebudayaan daerah ini memiliki sejumlah ciri yang tak bisa hilang yang dapat disebut sebagai keajegan tradisi. Dalam OVJ penjagaan terhadap keajegan wayang wong dengan memperhatikan unsur penting berupa adanya sang dalang, wayang, dan juga sinden.
Selanjutnya, keberadaan kesenian yang berada pada dua alam ini disebabkan seni tradisi mengalami saduran. Penyaduran ini telah menempatkan seni tradisi untuk dibentuk kembali oleh kebutuhan suatu kebudayaan yang lebih luas dan tidak sekadar menganut cita rasa tardisi asalnya. Hal ini menyebabkan lahirnya sebuah seni baru, yaitu seni kitch. Seni tradisi yang pada mulanya dimiliki lingkungn keraton atau kerajaan, kini juga dapat dimiliki oleh masyarakat luas atau luar istana. Kepemilikannya pun tidak dapat dengan mudahnya menyebut seni tradisi sebagai milik semua orang. Dalam lingkungan keraton, wayang wong tentunya tetap mempertahankan bentuk yang ada tanpa memperhatikan perkembangan zaman.

Apa yang di alami oleh OVJ sebenarnya merupakan jawaban dari pertanyaan Edy Sediawati dalam bukunya Pertumbuhan Seni Pertunjukkan. Seni tradisi seperti wayang wong, telah mengalami pergeseran kepemilikan. OVJ sebagai sebuah bentuk pertunjukkan yang dapat disajikan di luar lingkungan kebudayaan aslinya maka para penonton akan cenderung untuk menghargai sebagai sesuatu yang disebut Edy Sediawati, yaitu sesuatu yang eksotis dan bukan hal yang biasabiasa saja. OVJ telah menempatkan kepopulerannya di lingkungan Indonesia dengan menampilkan sesuatu yang baru, inovatif, dan kita pun menikmatinya.

Edy Sediawati memaparkan dua tuntutan dalam perkembangan atas seni tardisi yang kemudian menjadi populer ini. Pertama, para penggemar dari luar lingkungan tradisi tersebut menginginkan pemeliharaan atas gayanya yang khas, sedangkan penggemarnya dari dalam 
lingkungannya ada yang menginginkan tetap aman dalam gayanya yang telah terkenal secara akrab. Ada juga yang menginginkan perkembangan dalam arti perubahan atau tambahan sesuai dengan perubahan zaman (Sedyawati, 1981: 39). Sementara itu, dalam perkembangannya, seperti yang telah disebutkan di awal, perpaduan dua budaya yang di alami oleh OVJ merupakan bentuk dari seni kitsch. Bentuk kesenian seperti ketoprak, wayang wong komersil (OVJ), dan ludruk dianggap sebagai seni tradisional karena kelahirannya dan pertumbuhannya sebagai seni berada di lingkungan istana atau kota. Seni tradisi pun kemudian dapat disamakan dengan pop art menurut "barat" karena kepemilikannya yang minoritas. Selain itu, ketoprak dan wayang wong komersil (OVJ) dapat juga dikatakan sebagai seni rakyat atau seni populer karena kepemilikannya yang dimiliki oleh orang banyak. Karakteristik sebuah seni yang lahir dan tumbuh di lingkungan kerajaan atau kota dan dapat dikonsumsi orang banyak oleh Umar Kayam dipakai sebagai kriteria untuk menggolongkan suatu kategori kesenian yang disebut kesenian Kitsch. Umar kayam menggunakan 'Kitsch' untuk menggolongkan bentuk-bentuk kesenian yang tidak dapat disebut kesenian istana dan juga bukan kesenian rakyat, dan ia tidak membuat pertimbangan nilai kepada kualitas bentuk-bentuk kesenian tersebut (dalam Bahasa Inggris sehari-hari, 'kitsch' berarti murah, norak). Ini menunjukkan pentingnya memahami bagaimana istilah ini dan istilah lainnya digunakan dalam konteks Indonesia dan kita harus berusaha sangat cermat untuk memahami kata-kata yang sudah diindonesiakan (Lindsay, 1999: 46).

Legitimasi kitsch pada OVJ terletak dari formulasi penyaduran seni tradisional wayang wong dalam bentuk yang baru. Wayang wong yang aslinya hanya dapat dinikmati atau mungkin dimiliki kalangan kerajaan saja, berkat format baru dari OVJ menjadikan wayang wong dimiliki orang banyak. Bentuk penyaduran dalam OVJ tentunya dengan memperhatikan beberapa aspek dari cerita hingga aksesori pertunjukkan. Beberapa di antaranya penyaduran atau perubahan yang dilakukan OVJ pada seni wayang wong adalah waktu, bahasa, dan cerita.

Bahasa, sesuai dengan tempat kelahirannya, yaitu Yogyakarta; wayang wong menggunakan bahasa keratin atau bahasa Jawa. Berbeda dengan OVJ yang menggunakan bahasa keseharian. Mencoba untuk menyarkan akan pentingnya kepemilikan terhadap budaya tardisional dan juga bukti bahwa kebudayaan Indonesia adalah puncak kebudayaan daera maka bahasa Indonesia di pilih dalam pementasa OVJ. Bahkan, dalam pementasan tak jarang atau memang sebagai bahasa dialognya, yang digunakan adalah bahasa Jakarta atau bahasa percakapan. Dapat dilihat contoh dari pantun Parto yang bertindak sebagai dalang, yaitu "Di sini gunung di sana gunung, wayangnya bingung dalangnya juga bingung, yang penting bisa ketawa." Pantun yang di ucapkan sang dalang dapat memperlihatkan pembahasaan dalam OVJ. Percakapan yang disampaikan tidak juga memiliki ajeg dalam keinovasian. Hal ini disebebkan karena titik utama dari komedi ini adalah improvisasi sang pemain atau wayang dengan bermain dalam lingkungan wayang wong. Tentunya, pembahasaan pada OVJ tidaklah begitu penting selama dapat memancing pemirsa merasa terhibur atau tertawa. Itulah yang dikatakan Parto, "yang penting bisa ketawa." 
Secara keseluruhan, waktu wayang (kulit atau wong) dibagi menjadi tiga bagian atau pathet yang proporsinya dari penggambaran naratif, komplikasi, dialog dan gerakannya, kontras satu dengan yang lainnya. Lamanya waktu pementasan selama hampir delapan jam. Empat jam bagian pertama, yaitu pukul 09.00-01.00 merupakan pementasan bagian pertama 'pathet them.' Bagian kedua, pathet sanga, biasanya berlangsung paling lama selama dua jam antara pukul 01.0003.30. Kemudian bagian yang terakhir, pathet manyura, biasanya yang paling pendek berlangsung selama satu setengah jam antara 03.30-05.00. Dapat disimpulkan kalau pementasan wayang wong berlangsung dari pukul 09.0005.00 (Lindsay, 1999: 121).

OVJ yang merupakan saduran dari wayang wong mungkin tak bermaksud untuk memotong waktu pementasan dengan alasan keajegan atau habisnya jalan cerita. Alasan utamanya tentu saja durasi waktu yang disediakan stasiun televise Trans7. OVJ yang disiarkan secara off air berlansung antara pukul 20.00-21.00. Namun, durasi satu jam yang singkat itu di manfaatkan dengan mengefektifkan sebuah cerita. Bahkan, terkadang tak begitu penting isi ceritanya. Isi cerita hanya berguna sebagai pemantik kreativitas pemain dalam berperan. Durasi satu jam dengan cerita selesai dicoba untuk ditambah berupa intensitas siaran, yaitu dari hari senin sampai jumat.

Dari segi cerita, jelaslah sudah kalau dalam wayang wong, cerita yang kerapkali ditampilkan adalah kisah Ramayana dan Mahabarata. Dalam OVJ dengan aksesorisnya yang berbau kerajaan, terutama untuk dalangnya yang selalu menggunakan pakaian daerah dan ditemani sindennya yang juga menggunakan kebaya Jawa. Cerita dalam OVJ tidak terpaku pada cerita kerajaan. Tak jarang memang cerita yang ditampilkan adalah cerita rakyat atau kerajaan. Namun, intensitas terbanyak adalah cerita modern atau mungkin karangan tim kreatif dari OVJ yang jauh dari tema-tema yang sudah dikenal.

\section{Metode Penelitian}

Agar penelitian ini dapat memberikan hasil yang baik, maka penulisan laporannya menggunakan berbagai macam data, keterangan data, serta informasi penting yang diperoleh dari berbagai sumber, didasarkan pada jenis data, yaitu:

Data primer adalah berupa tayangan OVJ dalam satu bulan, yang dipilih dengan menitik beratkan judul-judl tayangan dengan setting cerita Jawa saja. Hal ini dilakukan mengingat juduljudul di Opera Van Java sangat bervariasi, dengan cerita yang tidak hanya dari latar belakang budaya Jawa.

- Episode Joko Tingkir, tayang 10 Oktober 2011.

- Episode Ajian Naga Hijau, tayang 19 Oktober 2011.

- Episode Jaka Tarub, tayang 27 Oktober 2011.

Data sekunder diperoleh dari studi kepustakaan dan wawancara pada pihak-pihak yang terkait untuk melengkapi data primer.

Sementara itu, penelitian kualitatif adalah prosedur penelitian yang menghasilkan data deskriptif berupa ucapan atau tulisan dan perilaku yang didapat dari mengamati subyek itu sendiri. Pendekatan ini langsung menunjukkan setting dan individu secara keseluruhan. Subyek penyelidikan baik berupa organisasi atau pun individu tidak dipersempit menjadi variabel yang terpisah atau menjadi hipotesis melainkan dipandang sebagai bagian dari satu keseluruhan (Bogdan \& Steven J Taylor, 2009: 21- 
22). Dalam pengertian ini tidak ada populasi, dan sample bersifat purposive yakni tergantung pada tujuan, dan fokus pada suatu waktu.

Selanjutnya, analisa data dalam penelitian ini dilakukan dengan tahapan-tahapan sebagai berikut:

a. Melihat tayangan OVJ kemudian merekamnya.

b. Mentranskrip data-data yakni mengelompokkan data-data yang mempunyai kecenderungan ciri yang sama berdasarkan indikator nilainilai Jawa.

Indikator yang disusun berdasarkan pada 2 kategori:

1. Hormat.

2. Rukun.

Hormat terdiri dari 3 sub kategori:

1. Sungkan: adalah rasa malu positif yang dirasakan apabila berhadapan dengan atasan (hubungan secara hirarkis). Sungkan terdiri dari sub kategori : patuh pada perintah atasan (verbal non verbal) dan setia mengabdi.

2. Isin/ malu: Orang Jawa akan merasa malu apabila ia tidak dapat menunjukkan rasa hormat yang tepat terhadap orang yang pantas dihormati. Sedangkan sub kategorinya: tahu menempatkan diri, tidak sombong, malu bila berbuat salah.

3. Saling menghargai: adalah suatu keadaan dimana hubungan dalam masyarakat diatur secara hirarkis, bahwa keteraturan itu bernilai pada dirinya sendiri dan oleh karena itu orang yang bersangkutan wajib membawa diri. Terbagi dalam sub kategori: saling menghargai antara atasan bawahan dan sebaliknya, antara anak dengan orang tua dan sebaliknya, suami istri dan sebaliknya, saudara dengan saudara, menghargai orang yang baru kenal.

Rukun terdiri dari 3 sub kategori:

1. Saling menyayangi: Adalah suatu keadaan dimana antar individu yang satu dengan yang lainnya atau kelompok dengan kelompok lainnnya menunjukkan rasa kasih sayang. Sub kategori: saling memberi perhatian, saling memberi dukungan moral.

2. Tolong menolong dan gotong royong: praktek gotong royong pun mewujudkan kerukunan yaitu melakukan pekerjaan bersama dan saling membantu demi kepentingan bersama. Sub kategori: membantu memecahkan masalah, memberi bantuan material, membela saudara atau teman.

3. Penuh keakraban: suasana akrab adalah interaksi dimana tidak ada ketegangan dan merupakan hubungan sosial yang santai. Sub kategori: bercanda dengan sesama teman.

Sementara itu, tipe penelitian yang digunakan dalam penelitian ini adalah penelitian deskriptif. Tipe penelitian kualitatif mampu mendekatkan peneliti dengan objek yang dikaji. Dengan sifatnya yang deskriptif, maka dapat menggambarkan secara rinci fenomena tertentu. Menurut Robert Bogdan dan Steven J Taylor, penelitian kualitatif adalah prosedur penelitian yang menghasilkan data deskriptif berupa ucapan atau tulisan dan perilaku yang dapat diamati dari orang-orang (subyek) itu sendiri. Pendekatan ini langsung menunjukkan setting dan individuindividu dalam setting secara keseluruhan. Subjek penyelidikan, baik berupa organisasi ataupun individu 
tidak dipersempit menjadi variable yang terpisah atau menjadi hipotesis melainkan dipandang sebagai bagian dari keseluruhan (Arif Farhan, 1992: 22). Penelitian kualitatif juga dipandang lebih mendalami masyarakat secara arif tentang vision $d u$ monde (pandangan dunia) mereka. Karenanya penelitian kualitatif adalah pelopor pendekatan dalam menguji dunia empiric yang memerlukan para peneliti mengintepretasikan dunia nyata berdasar perspektif dari obyek yang ditelitinya.

\section{Hasil Penelitian dan Pembahasan}

Dari penampilan tiga sample penelitian diperoleh kenyataan bahwa tayangan OVJ di televisi telah mengalami pergeseran nilai-nilai budaya Jawa. Maksud dari pergeseran nilai adalah bahwa nilai-nilai dasar Jawa sebenarnya masih ada dan berbentuk sama jelasnya seperti dulu hanya saja ia tidak berperan secara dominan.

Sementara itu, dari tiga sample obyek penelitian berupa rekaman tayangan OVJ episode Joko Tingkir, Ajian Naga Hijau dan Joko Tarub, maka berikut adalah deskripsi masing-masing episode:

\section{Joko Tingkir}

Sinopsis: Diceritakan seorang pemuda yang bernama Joko Tingkir hidup di hutan bersama Ibunya. Untuk mengasah kemampuannya, Joko Tingkir berguru kepada Ki Ageng Banyubiru. Suatu hari ketika sedang berlatih di hutan, Joko Tingkir didatangi oleh seseorang yang meminta bantuannya karena kakinya sakit. Joko Tingkir tidak tahu bahwa orang tersebut sebenarnya adalah putri Sultan Trenggono yang menyamar menjadi orang biasa agar mengetahui kemampuan Joko Tingkir. Hingga suatu hari kedok orang itu terbuka sehingga nampak identitas aslinya yakni Ratu Mas Cempa. Joko Tingkir menaruh hati pada putri itu, namun mendapat tantangan dari Dadung Kawuk. Akhirnya perebutan simpati itu dimenangkan oleh Joko Tingkir.

Nilai hormat: Nilai hormat pada episode ini secara keseluruhan hanya nampak pada kategori hormat dan patuh pada orang tua dan guru. Sikap menghargai ditampilkan dalam bentuk verbal dengan penggunan kosakata "guru" setiap kali Joko Tingkir memanggil gurunya. Secara non verbal, sikap tubuh juga menunjukkan penghormatan kepada orang lain, seperti membungkuk, memberi hormat dan bersimpuh. Nilai hormat juga dieksplorasi pada hubungan anak kepada orang tuanya. Sikap Joko Tingkir menjaga kehormatan Ibunya dengan membiarkan orang tuanya itu menunjukkan wibawa di antara tamunya.

Nilai rukun: Pada episode ini, nilai rukun ditemukan pada suasana percakapan antara Joko Tingkir dengan teman baiknya, yang masuk dalam kategori memberi perhatian. Joko Tingkir memberi ucapan selamat datang dan ikut senang karena sahabat karibnya itu telah berhasil menangkap kijang di hutan. Ucapan ini menunjukkan bahwa kerukunan perlu dijaga dengan datang langsung memberi ucapan, agar hubungan kedua belah pihak semakin akrab dan mempertebal persahabatan. Kerukunan juga ditunjukkan dengan musyawarah, meminta pendapat kepada sahabat Joko Tingkir untuk mengahdapi persaingan dengan Dadung Kawuk. Suasana akrab yang terbangun diantara dua orang ini menunjukkan tingkat kerukunan mereka, karena bahasa yang digunakan juga rileks dan setara. Dalam babak ini pula ditunjukkan bagaimana mengatasi konflik yang disebabkan karena perbedaan pendapat. Seperti disebutkan oleh Ann. R Wilner, dalam 
perspektif Jawa ketenangan dan keselarasan sosial merupakan keadaan normal yang akan terdapat dengan sendirinya selama tidak diganggu (Frans Magniz, 1998: 40).

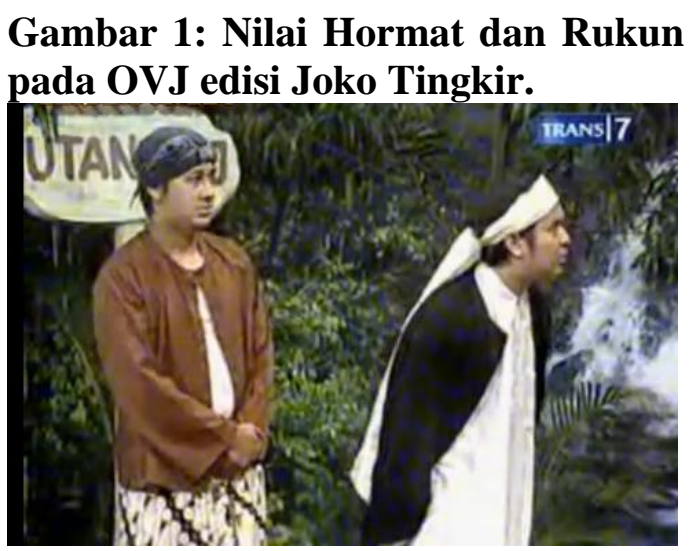

Sikap tubuh murid terhadap guru yang ditunjukkan dengan gerakan ngapurancang / melipat tangan di bawah dengan sopan. Tidak berani mendahului langkah gurunya.

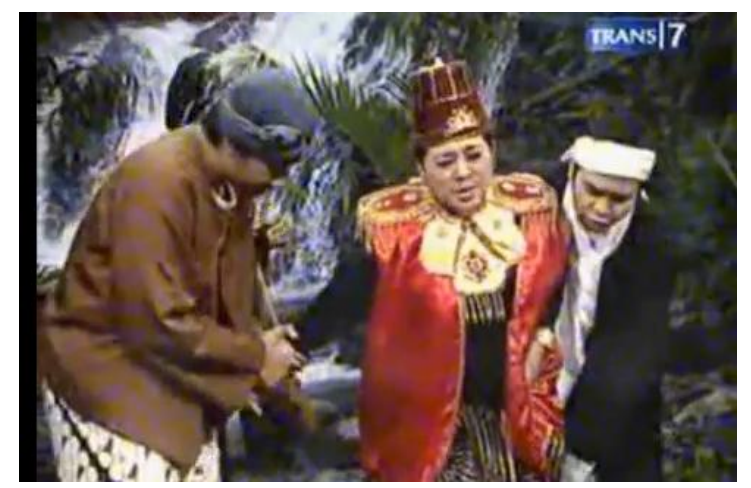

Membantu Raja dan guru pada saat ada masalah, serta menggunakan sebutan "Raja", "Guru" sebagai bentuk penghormatan.

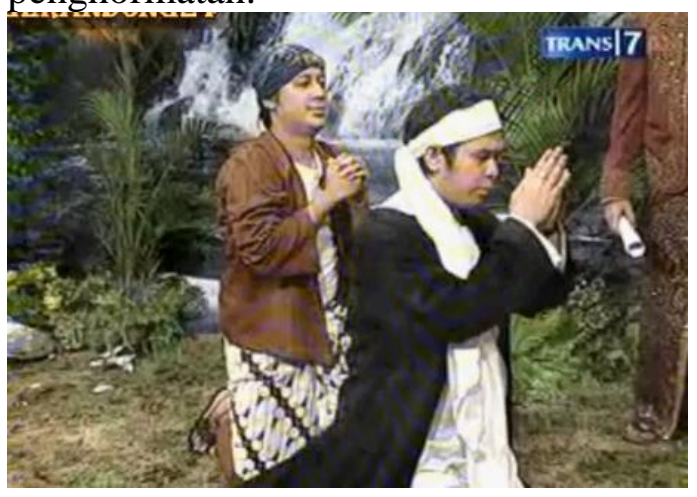

Gerakan menyembah kepada Raja sebagai bentuk penghormatan atas hubungan antara atasan dengan bawahan.

\section{Ajian Naga Hijau}

Sinopsis: Di keraton Selowangi baru saja terjadi pergantian senopati, karena senopati yang lama yakni Senopati Ayuda dianggap tidak mampu melaksanakan tugasnya. Oleh karenanya Senopati Ayuda diganti oleh Tunggul seto, senopati muda yang bertanggung jawab. Senopati Ayuda dan istrinya yang sakit hati berencana membalas dendam kepada Raja Joyogupito dengan mengobrak-abrik istana. Namun niat jahat itu akhirnya dapat digagalkan, dan kedua pihak yang bermusuhan dapat saling memaafkan.

Nilai hormat: Dari seluruh adegan Ajian Naga Hijau, nilai hormat ditemukan dalam babak menjelang epilog. Babak akhir menampakkan setting kerajaan, di mana Raja duduk di singgasana didampingi permaisurinya. Sementara para bawahan duduk di bawah dengan kaki bersila. penempatan posisi yang ditata sedemikian rupa itu telah menggambarkan kedudukan atau status sosial yang berbeda antara atasan dengan bawahan. Meski demikian ada beberapa adegan yang justru bertentangan dengan nilai hormat kategori kesetiaan mengabdi. Ada sebuah adegan yang memperlihatkan abdi berani membantah ucapan atasannya dan berkesan sembrono. Selain itu juga, diperlihatkan adegan tidak sopan dan cenderung mengarah pelecehan harga diri seseorang. Ditampakkan adegan memukul pantat, sehingga adegan seperti itu dinilai berlawanan dengan nilai hormat. Dalam pandangan orang Jawa, tingkah laku yang penuh dengan hawa nafsu adalah berbahaya karena nafsu-nafsu adalah perasaan kasar yang dapat menggagalkan kontrol diri manusia dan 
membelenggunya pada dunia lahiriah. Manusia yang dikuasai hawa nafsu, dapat mengancam lingkungannya, menimbulkan konflik dan membahayakan ketentraman. Secara ekstrem, Cliford Geertz bahkan menyebut tingkah laku yang masih dikuasai oleh nafsu dan emosi hanya pantas disandang predikatnya oleh anak-anak, binatang dan orang gila.

Nilai rukun: Lain dengan nilai hormat yang tidak mudah ditemui dalam setiap babak, nilai rukun dalam episode ini ditemui hampir dalam setiap babak, kecuali babak pertama karena pada babak ini hanya dijumpai adegan perang antara naga dan prajurit. Pada babak berikutnya, nilai rukun ditunjukkan dalam percakapan yang dilakukan abdi dalem yang menunjukkan nilai rukun dengan kategori memberi perhatian dan membantu memecahkan masalah. Selain itu nilai rukun juga ditunjukkan pada gerakan tubuh saling menyayangi antara raja dan permaisurinya. Gerakan non verbal ditunjukkan dengan duduk satu bangku dengan posisi sangat dekat dan mesra. Nilai rukun lainnya adalah pada sebuah babak musyawarah. Orang Jawa tidak jemu-jemu menunjuk pada keunggulan musyawarah jika dibandingkan dengan cara Barat untuk mengambil keputusan melalui pemungutan suara. Adalah tujuan musyawarah agar setiap orang bisa mengemukakan pendapatnya sehiingga keputusan tidak diambil satu pihak saja yang unggul. Kerukunan menuntut dari pihak-pihak yang berlawanan untuk melepaskan keinginan pribadi yang akan menimbulkan keresahan sosial terbuka (Hildred Geertz, 1995: 48).

\section{Gambar 2: Nilai Hormat dan Rukun pada Tayangan Naga Hijau.}

Adegan hulubalang mengetuk pintu menjadi representasi dari nilai hormat yang masih digunakan dalam tayangan ini.

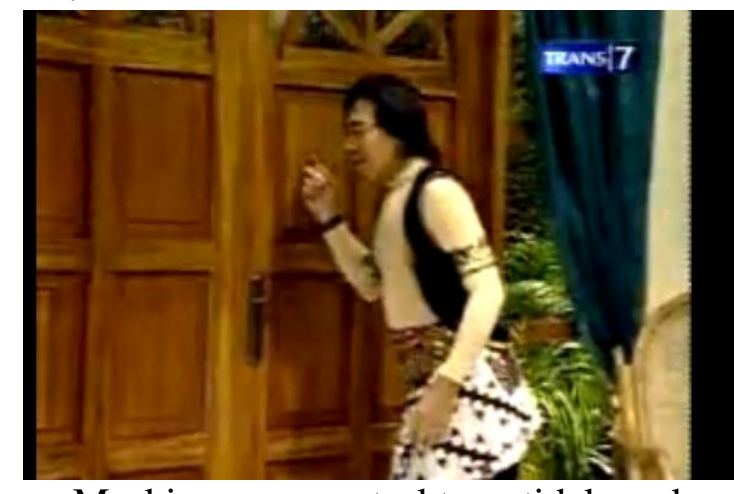

Meski secara struktur tidak ada hubungan yang setara (pembantu dan majikan) namun suasana percakapan yang terbangun masih menunjukkan nilai kerukunan, karena membahas sebuah persoalan dan mencari jalan tengahnya.

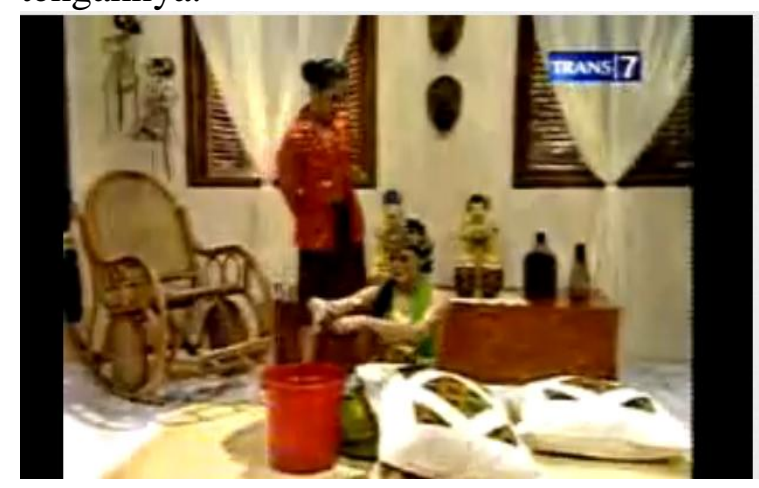

Joko Tarub

Sinopsis: Dikisahkan seorang pemuda bernama Joko Tarub sedang berjalan-jalan di hutan, lalu memergoki para bidadari yang sedang mandi di air terjun. Joko Tarub mengambil salah satu selendangnya, lalu memikat satu dari bidadari itu untuk dijadikan istrinya. Kemudian istri Joko Tarub hidup di desa sebagai Ibu rumah tangga biasa, hingga akhirnya ia menemukan selendang yang dulu disembunyikan Joko Tarub. Istri Joko Tarub marah lalu ia pergi kembali ke kahyangan meninggalkan Tarub dan keluarga kecilnya di desa.

Nilai hormat: Dalam episode ini nilai hormat yang ada tidak tercermin dengan sempurna. beberapa adegan sering terlihat tidak konsisten dengan 
komitmen awalnya. Banyak adegan dimana masing-masing pemain saling menyelan pembicaraan dengan katakata yang seharusnya tidak diucapkan. Nilai hormat dengan kategori tahu menempatkan diri dengan sendirinya tidak berhasil ditunjukkan oleh para pemain. Seorang pemain yang ditempatkan pada strata sosial yang lebih rendah (abdi) seharusnya dapat mencerminkan kemampuannya untuk menmpatkan diri. Juga terlihat adegan yang melanggar batas-batas kesopanan. Padahal menurut aturan pakem wayang wong, unggah-ungguh (kesopanan) sebagai ciri tradisi Jawa tidak boleh ditinggalkan.

Nilai rukun: Digambarkan dalam berbagai percakapan yang dilakukan dengan akrab, menyanyi dan menari penuh dengan suasana hangat. Suasana kekeluargaan juga terbangun dengan baik pada adegan keluarga Joko Tarub di desa. Bahkan pada tetangga pun juga diperlakukan penuh suasana kekeluargaan. Orang Jawa berusaha memperlakukan orang lain seperti anggota keluarga, dan tidak begitu senang untuk mengetahui dengan persis tingkat hubungan kekeluargaan dengan anggota keluarga walaupun ia mengetahui dengan persis (Hildred Geertz, 1995: 153). Keyakinan Jawa selalu mencegah dan mengecilkan kecondongan-kecondongan yang dapat memisahkan atau menimbulkan pertentangan antar individu. Itulah mengapa orang Jawa selalu menyapa orang asing dengan sebutan "pak", "bu", "mbah", 'pakdhe", 'dik", "mas", dan seterusnya.

\section{Gambar 3: Nilai Hormat dan Rukun pada Tayangan Jaka Tarub.}

Menari dan menyanyi bersama dengan akrab, menandakan keakrakab dan kerukunan.

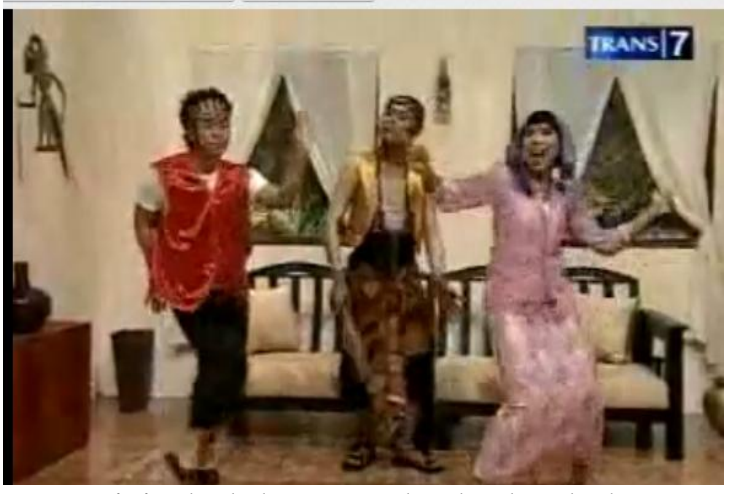

Posisi duduk yang berbeda, bahasa non verbal yang menunjukkan hubungan tidak setara, sehingga gerakan ini dinilai mewakili nilai hormat.

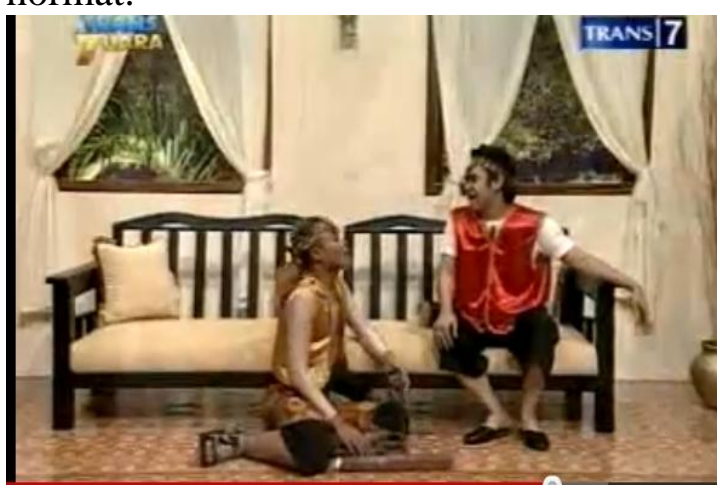

\section{Penutup}

Temuan dari penelitian ini dapat disebutkan bahwa tayangan Opera Van Java di layar televisi pada dasarnya membawa nilai-nilai budaya Jawa, namun telah banyak mengalami pergeseran. Pergeseran nilai-nilai budaya Jawa dilihat dari peran dan fungsinya yang tidak dominan lagi. OVJ yang merupakan seni pertunjukkan komersial, membuat nilai-nilai budaya Jawa yang mendasar itu tidak begitu dipentingkan lagi. Penelitian tentang pencarian nilai dan hormat di tayangan wayang orang modern seperti OVJ masih dapat dilakukan, mengingat akar budaya aslinya adalah masyarakat Jawa. hanya saja karena format dan bentuknya media yang berbeda, sehingga otomatis menjadi manifestasi konkrit budaya pop. Budaya pop mengandung ciri 
instan, memberikan pemuasan sesaat, pasif, cenderung dangkal, dan tidak membutuhkan banyak usaha atau pengetahuan untuk menikmatinya (Ibrahim, 2005: 34).

Pada penelitian yang menggunakan tiga sampel tayangan OVJ yaitu episode Joko Tingkir, Ajian Naga Hijau, dan Joko Tarub, tim peneliti menemukan pola komunikasi yang digunakan dalam setiap pementasan. Segala nilai-nilai hormat yang berkaitan dengan suatu status dalam masyarakat tidak lagi diperhatikan. Orang Jawa menggunakan kata hormat dalam arti menunjukkan kata hormat dengan jalan menerapkan tata sopan santun yang benar. Dalam tata lahirnya, orang Jawa harus menghargai tatanan menghormati orang yang lebih tua dan pemimpinnya, serta bersikap bijak terhadap para bawahan dengan menggunakan ukuran bagi diri sendiri (tepa selira). Dengan kata lain, berlaku prinsip timbal balik. Disamping itu orang juga harus memperhatikan hubungan yang harmonis dan menghindari semua konflik terbuka. Agar dapat melakukannya, orang tidak hanya memiliki pengetahuan tetapi juga harus menguasai dirinya, emosi, dan dorongan-dorongan dalam diri. Tuntutan nilai yang ada dalam masyarakat Jawa ini bila dipertemukan dengan pola komunikasi pada hasil penelitian akan menjadi hal yang menyimpang. Dikatakan menyimpang karena dalam OVJ tidak ditemukan suatu bentuk penghormatan yang mutlak dari bawahan kepada atasan sesuai dengan nilai-nilai hormat. Konflik sengaja dibiarkan berkembang, dan diciptakan dengan sengaja karena untuk memenuhi unsur-unsur cerita. Hubungan atasan dan bawahan yang lemah disebabkan karena masingmasing atribut peran tidak berfungsi sebagai indikator status.
Pada penayangan OVJ, selalu dijumpai adegan-adegan yang bersifat slap stick yakni lawakan yang disertai dengan gerak isyarat dan bahasa tubuh kocak dan cenderung kasar, seperti pukul-pukulan dan sebagainya. Lewat adegan slap stick ini seringkali tata krama dan nilai hormat kepada orang lain menjadi tipis, bahkan seringkali ditambah dengan adegan yang jelasjelas sudah keluar dari bingkai budaya Jawa. Misalnya mengeluarkan celetukan jorok, memegang kepala, menepuk pantat, dan lain sebagainya. Isi nilai hirarki mengalami perubahan karena hirarki hanya menjadi tatanan kekuasaan dan komando yang telah kehilangan kharisma dan tradisi yang dapat diterima.

Gambar 4: Adegan Slap stick yang Banyak Bermunculan di OVJ sebagai Bagian dari Budaya Pop.

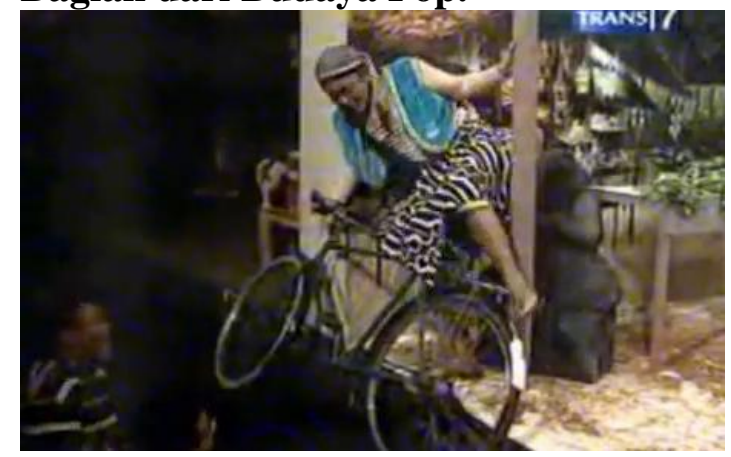

Bercakap-cakap dengan akrab, namun meninggalkan norma kesopanan dalam masyarakat.

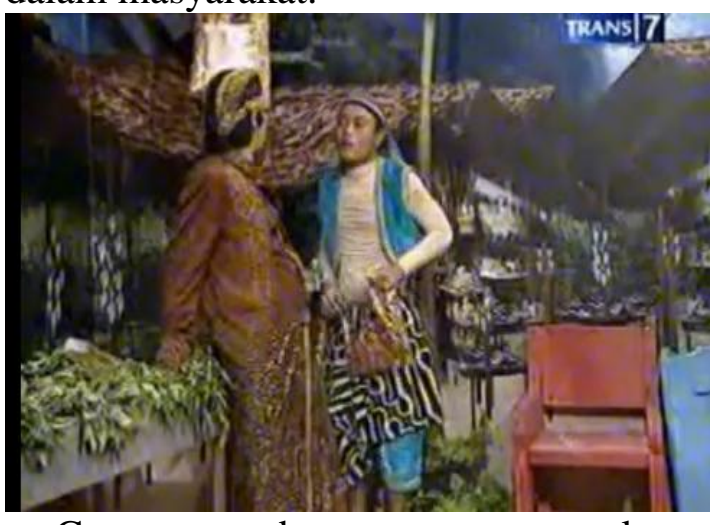

Guyonan dengan menggunakan pukul-pukulan dan cenderung kasar, asal memancing tawa bagian dari humor budaya massa. 


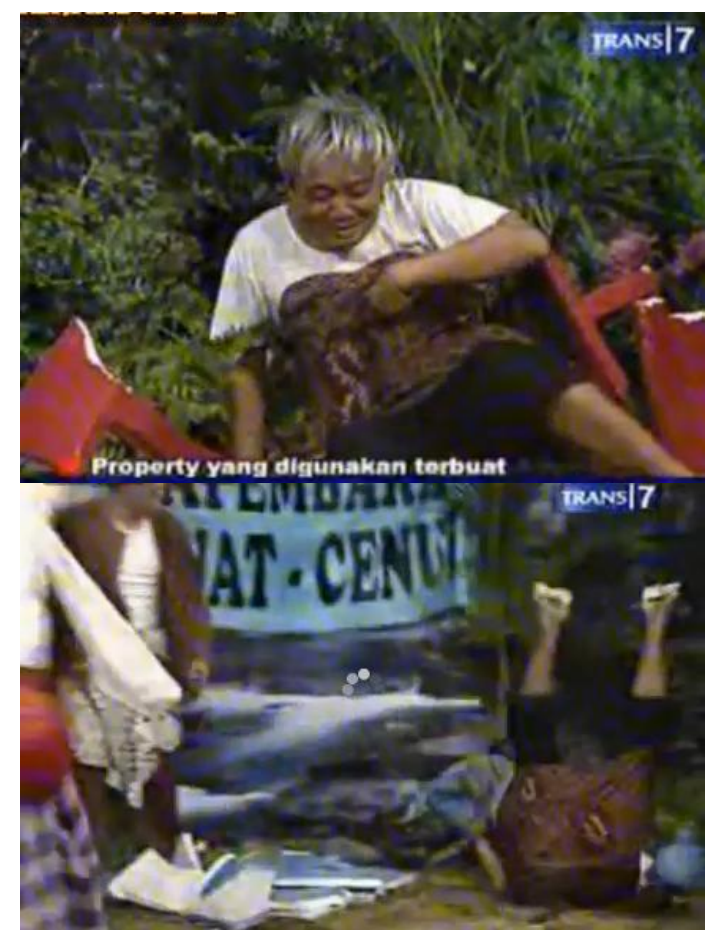

Sekalipun banyak adegan yang bersifat slap stick namun dalam babak eksplorasi humor itu nilai rukun masih ada. babak ini biasanya diisi dengan bincang-bincang santai dan akrab. Adegan musyawarah untuk memecahkan masalah dan bergotong royong juga masih dapat dijumpai meskipun di sana-sini diselingi dengan lawakan.

Sementara itu, konsep wayang orang sejak dari semula adalah hiburan yang tumbuh dari tengah-tengah masyarakat Jawa. Wayang orang sebagai sebuah seni pertunjukan memiliki dimensi sebagai pelipur lara atau hiburan. dalam konteks ini tidak diingkari bahwa halhal yang bersangkutan dengan citarasa menjadi unsur-unsur yang sangat diperhatikan. Wayang orang juga mempunyai dimensi substansial dalam keseimbangan yang tepat. Oleh karenanya, karya seni pertunjukkan ini akan lebih berguna dalam masyarakat jika pesan sang seniman berupa nilainilai, penghayatan kehidupan, hati nurani, perhatian, cinta, hakekat hidup dan sebagainya dapat tersampaikan dengan tepat. Kepada para pekerja seni
OVJ, alangkah bijaksananya bila dapat mengingat kembali fungsi wayang orang seperti yang disebutkan di atas. Artinya, dalam setiap pementasan OVJ sekalipun sudah dikemas dalam bentuk humor jangan sampai melupakan nilainilai asal yang melingkupinya, karena bagaimanapun kesenian ini berasal dari Jawa. Akan menjadi pemikiran bagi generasi penerus bangsa apabila penampilan OVJ menjadi sangat miskin nilai-nilai kejawaannya, karena seiring waktu akan semakin terjadi pergeseran nilai-nilai apabila tidak ada plestarian. Mungkin akan lebih baik seandainya terdapat sebuah rumah produksi yang khusus terkonsentrasi pada permasalahan pemeliharaan seni budaya Indonesia, khususnya seni budaya yang belum pernah terangkat di permukaan. Dengan demikian masih terdapat harapan untuk generasi mendatang untuk dapat menyaksikan kekayaan kebudayaannya sendiri dengan utuh.

\section{Daftar Pustaka}

Bride, Mac. 2010. Aneka Suara Satu Dunia (Komunikasi dan Masyarakat Sekarang dan Masa Depan). Jakarta: Balai Pustaka.

Burton, Graeme. 2008. Media dan Budaya Populer. Yogyakarta: Jalasutra.

Danarka Sasangka. 2008. Diskursus Relasi Masyarakat, Bisnis dan Media. Yogyakarta: FISIP Universitas Atma Jaya.

Edi Sedywati. 1981. Pertumbuhan Seni Pertunjukkan. Jakarta: Sinar harapan.

Geertz, Hildred. 1995. Keluarga Jawa. Jakarta: PT Grafiti Pers.

Haryatmoko. 2007. Etika Komunikasi: Manipulasi Media, Kekerasan, dan Pornografi, Bandung: Kanisius.

Idi Subandi Ibrahim. 2005. Lifestyle Ectasy: Kebudayaan Pop dalam 
Masyarakat Komoditas Indonesia. Yogyakarta: Jalasutra.

Lindsay, Jennifer. 1999. Klasik Kitsc Kontemporer, Sebuah Studi Tentang Pertunjukan Jawa. Yogyakarta: Gajah Mada University Press.

Rachel, James. 2004. Filsafat Moral (Terjemahan A. Sudiardja). Yogyakarta: Kanisius.

S. Nasution. 2000. Metode Penelitian Kualitatif Naturalistik. Bandung: PT Tarsito. 